\title{
Periodicity of Inflorescence Initiation and Development in Nerine bowdenii W. Watson (Amaryllidaceae)
}

\author{
K.I. Theron and G. Jacobs \\ Department of Horticultural Science, University of Stellenbosch, Private Bag X5018, 7599 Stellenbosch, \\ Republic of South Africa
}

Additional index words. cut flower, scanning electron microscopy

\begin{abstract}
Nerine bowdenii bulbs were sampled from a commercial planting and dissected at 2-week intervals from 9 Oct. 1990 to 12 Nov. 1991. The following variables were recorded: number of florets per inflorescence, differentiation stage of the oldest floret, exterior dimensions of the inflorescence, and the number of leaf primordia between the two innermost inflorescences and between the innermost inflorescence and the vegetative apex. Scanning electron micrographs were made of the inflorescences at different stages of development. The development of the inflorescences of the growth units appeared to be synchronized. When the florets of the outermost inflorescence reached stage Late $G$ (gynoecium elongated, carpels fused), the spathe started to elongate. When florets in the second inflorescence reached stage Mid G (three carpels elongated, not fused), the innermost inflorescence was initiated. Inflorescence development passed through three phases: 1) a floret initiation phase of $\approx 1$ year, when nine to ten florets were initiated, 2 ) a differentiation phase, also $\approx 1$ year long, when individual florets developed up to stage Late $G$, and 3) an inflorescence enlargement phase, which lasted $\approx 4$ months and culminated in anthesis. Leaf primordia were initiated at the same rate as florets (one per month) and the vegetative phase for a growth unit was completed within 1 year.
\end{abstract}

Nerine bowdenii W. Watson (Amaryllidaceae) is a fall flowering, synanthous, perennial bulb indigenous to southern Africa ( Du Plessis and Duncan, 1989). The species grows in regions with summer rainfall and cold, dry winters. It is an important cut flower (Van Dijk, 1988). The scape bears an umbel-like compound inflorescence made of helicoid cymes (Dalgren et al., 1985). The bulb has many fleshy leaf bases and contains several inflorescences, one of which is produced annually (Rees, 1985; Van Brenk and Benschop, 1993). The bulbs have a growth period of $\approx 7$ months from planting until the leaves senesce, followed by a dormant period of $\approx 4$ months during winter (Rees, 1985; Van Brenk and Benschop, 1993). According to Sytsema (1971), a period of low temperature is necessary for flowering, and inflorescence abortion can limit flower production (Berghoef and Van Brenk, 1983).

This study was undertaken to determine the synchronization of stages of development in the bulb and to use this knowledge to determine possible reasons for nonflowering. In this paper, we report on the periodicity of inflorescence initiation, differentiation, and development in Nerine bowdenii.

\section{Materials and Methods}

Plant material. Bulbs from a commercial planting of Nerine bowdenii were used. They were grown in a $64 \%$ shade house in the Elgin region of the Western Cape ( lat. $33^{\circ} 54^{\prime} \mathrm{S}$ ). The light intensity in the shade house, recorded on a sunny day in midsummer at 1100 $\mathrm{HR}$, was $440 \mu \mathrm{mol} \cdot \mathrm{m}^{-2} \cdot \mathrm{s}^{-1}$. The Elgin climate is Mediterranean with cool, wet winters and dry, hot summers. The average annual rainfall is $\approx 1000 \mathrm{~mm}$ (Department of Agriculture and Water

Received for publication 22 Dec. 1993. Accepted for publication 19 May 1994. We thank A. Doorduin and S. Oudhuis, Oak Valley Flowers, for facilities, plant material, and supervision, P. van der Merwe and D. Janse van Rensburg for scanning electron microscopy assistance, and S.A. le Grange for editorial assistance. The cost of publishing this paper was defrayed in part by the payment of page charges. Under postal regulations, this paper therefore must be hereby marked advertisement solely to indicate this fact.
Supplies, 1989). Bulbs (12/14 cm in circumference) were stored for 3 months at $2 \mathrm{C}$ and planted on 1 Oct. 1990 at a density of 160 bulbs $/ \mathrm{m}^{2}$. They were irrigated, fertilized, and treated for pests according to standard commercial practices. After the flowers were harvested in April and the leaves had senesced, bulbs remained in situ and were grown for a second year.

Bulb unit terminology. Nerine bulbs are composed of a series of growth units (Van Brenk and Benschop, 1993). A growth unit has a vegetative phase during which leaves are formed, and a reproductive phase during which the apex is transformed into an inflorescence. At anthesis, in the fall, more than three growth units were evident per bulb (Fig. 1). The oldest growth unit consisted of the current season's inflorescence $(\mathrm{N})$, which is subtended by leaf bases. The second growth unit was composed of a developing inflorescence $(\mathrm{N}+1)$, which reached anthesis in the next fall, and was subtended by fully expanded leaves, which senesced during winter. Developing inflorescence $\mathrm{N}+2$, subtended by young, unexpanded leaves, constituted the third growth unit. The leaves of growth unit $\mathrm{N}+2$ expanded after winter, whereas the inflorescence $\mathrm{N}+2$ reached anthesis in the second fall. Two to three leaf primordia developed in the fourth growth unit $(\mathrm{N}+3)$, and the apex was vegetative (Fig. 1).

Data recorded. At 2-week intervals, from 9 Oct. 1990 to 12 Nov. 1991, ten bulbs (unless stated otherwise, see Fig. 4) were sampled at random from the commercial planting and brought to our laboratory. Bulbs were dissected and the following variables were recorded using a light microscope with HWF 10× eyepieces: 1) number of florets in inflorescences $\mathrm{N}, \mathrm{N}+1$, and $\mathrm{N}+2,2$ ) differentiation stage of the oldest floret in each inflorescence using the terminology proposed by Beyer (1942), 3) outside dimensions of inflorescences $\mathrm{N}$ and $\mathrm{N}+1$, and 4 ) the number of leaf primordia with fully sheathing bases in vegetative units $\mathrm{N}+2$, and $\mathrm{N}+3$ (Fig. 1).

As development progressed, inflorescences were prepared for scanning electron microscopy (SEM). They were fixed in FAA, ethanol-dehydrated, critical point-dried (Nell and Rasmussen, 1979) and sputter-coated with gold at $15 \mathrm{~m} \AA$ for $5 \mathrm{~min}$ in an ioncoater. Samples were viewed on a scanning electron micro- 


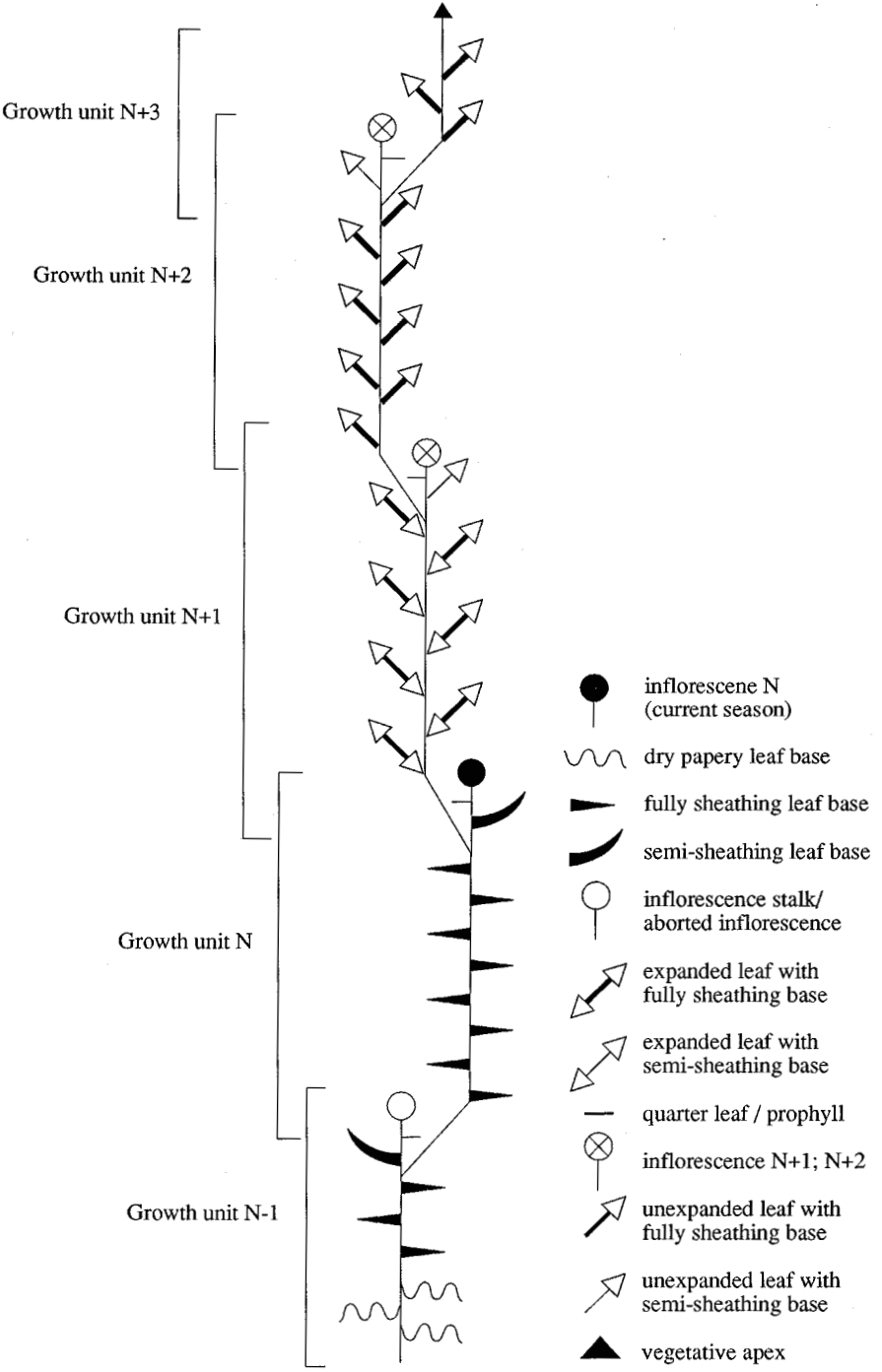

Fig. 1. A schematic representation of a Nerine bowdenii bulb at anthesis in the fall.

scope at an accelerating voltage of $25 \mathrm{kV}$. Micrographs were taken with a $6 \times 7-\mathrm{cm}$ camera using 125 ISO film.

\section{Results and Discussion}

Morphological changes of the apex surface during the transition from the vegetative to the reproductive phase are presented in Fig. 2 , while several developmental stages of the oldest floret are presented in Fig. 3. The inflorescence developed in the terminal position of the unit after leaf initiation had ceased. The vegetative phase was completed after the initiation of a leaf with a semisheathing base and a prophyll (Fig. 2A). The first indication of reproductive development was a slight increase in the height of the apical dome. This resembled development of Amaryllis belladonna L. (Hartsema and Leupen, 1942).

Subsequently, vegetative growth was resumed as evidenced by the initiation of a nonaddorsed leaf by the apical meristem in the axil of the last leaf with a full sheathing base. The first spathe valve primordium formed opposite the last semi-sheathing leaf (Fig. 2B). The second spathe valve developed directly opposite the first, followed by initiation of individual floret primordia (Fig. 2E). Florets were formed in a double bostryx, each branching in a clockwise direction (Fig. 2F). The first floret of the first bostryx was initiated in the axil of the first spathe valve, while the first floret of the second bostryx formed in the axil of the second spathe valve. Subsequent florets were initiated in the axils of bracteoles. Two perianth whorls were followed by the first and second whorl of each androecium. These preceded differentiation of three carpel initials, which elongated and fused (Fig. 3). Again, this is comparable not only to the development in A. belladonna (Hartsema and Leupen, 1942), but also to other species of Amaryllidaceae (Blaauw, 1931; Hartsema and Leupen, 1942; Luyten and Van Waveren, 1938, 1952). As with A. belladonna (Hartsema and Leupen, 1942), the slight and gradual increase in dome size obscured the demarcation between reproductive stages I and II. The second whorl of stamens started to develop before the first was completed, and the carpels were initiated before the second whorl of stamen initials was completed (Fig. 3B).

At planting (1 Oct. 1990), the apex of growth unit N+2 was vegetative. On average, three leaf primordia were present. Leaf initiation continued at a rate of about one leaf a month until 12 Mar. 1991, when the first bulbs were observed to be at the spathe valve initiation (Sp) stage (Fig. 4). This coincided with inflorescence $\mathrm{N}+1$ reaching stage Mid $\mathrm{G}$. The vegetative apex formed eight to nine plastochrons (excluding the semi-sheathing leaf) before becoming reproductive. No time lag occurred between the completion of the vegetative phase and the beginning of the reproductive phase. Simultaneous with the initiation of inflorescence N+2, the uppermost lateral bud started growing and the development of the vegetative phase of a new growth unit $(\mathrm{N}+3)$ began (Fig. 4). During winter, the rate of leaf initiation was slower. The overall period of leaf initiation in unit $\mathrm{N}+2$ lasted $\approx 1$ year (Fig. 4). Fewer leaf primordia were present in unit $\mathrm{N}+2$ at planting in 1990 when compared to unit $\mathrm{N}+31$ year later. Leaf initiation continued in bulbs left in situ during Winter 1991, while leaf initiation ceased during cold storage in Winter 1990 (data not presented). The average weekly minimum winter soil temperature (at the depth of the bulb) was $\approx 9 \mathrm{C}$, which is higher than the $2 \mathrm{C}$ during storage of the bulbs. Sytsema (1971) found that storage temperatures of 9 or $13 \mathrm{C}$ were detrimental to subsequent flowering of bulbs, but this was probably due to drying out of bulbs. We found that bulbs left in situ grew successfully despite the relatively high winter temperatures.

From 12 Mar. 1991 to anthesis of inflorescence N (14 May 1991), the development of inflorescence $N+2$ progressed through the Sp stage and the first phase of floret initiation (Pr). During the initial phase of Pr, the apical meristem divided to form two floret initials, one in each bostryx. When, on average, three florets were present, the oldest floret reached stage P1 (Fig. 4). This coincided with senescence of the $\mathrm{N}+1$ leaves. The rate of floret initiation $(\mathrm{N}+2)$ was similar to the rate of leaf primordia initiation $(\mathrm{N}+3)$ during both winter and spring (Fig. 4). Florets in inflorescence $\mathrm{N}+2$ did not reach stage A1 before the onset of winter.

Simultaneous with the development of new leaf primordia $(\mathrm{N}+2)$, inflorescence $\mathrm{N}+1$ continued to develop. At planting, coldstored bulbs contained two florets in an inflorescence and, on average, an additional seven florets had been initiated by the time inflorescence $\mathrm{N}$ reached anthesis (Fig. 4). After this, no further florets were initiated in inflorescence $\mathrm{N}+1$. Therefore, floret initiation occurred at a rate of about one per month. As was observed in the vegetative phase, the inflorescence was less developed at planting after cold storage during winter (two florets in $\mathrm{N}+1$ ) than when the bulbs had remained in situ during winter (3.5 florets in $\mathrm{N}+2$ ) (Fig. 4).

The oldest florets in inflorescence $\mathrm{N}+1$ were at stage $\mathrm{P} 1$ at planting. Differentiation continued, and stage Mid G was reached 

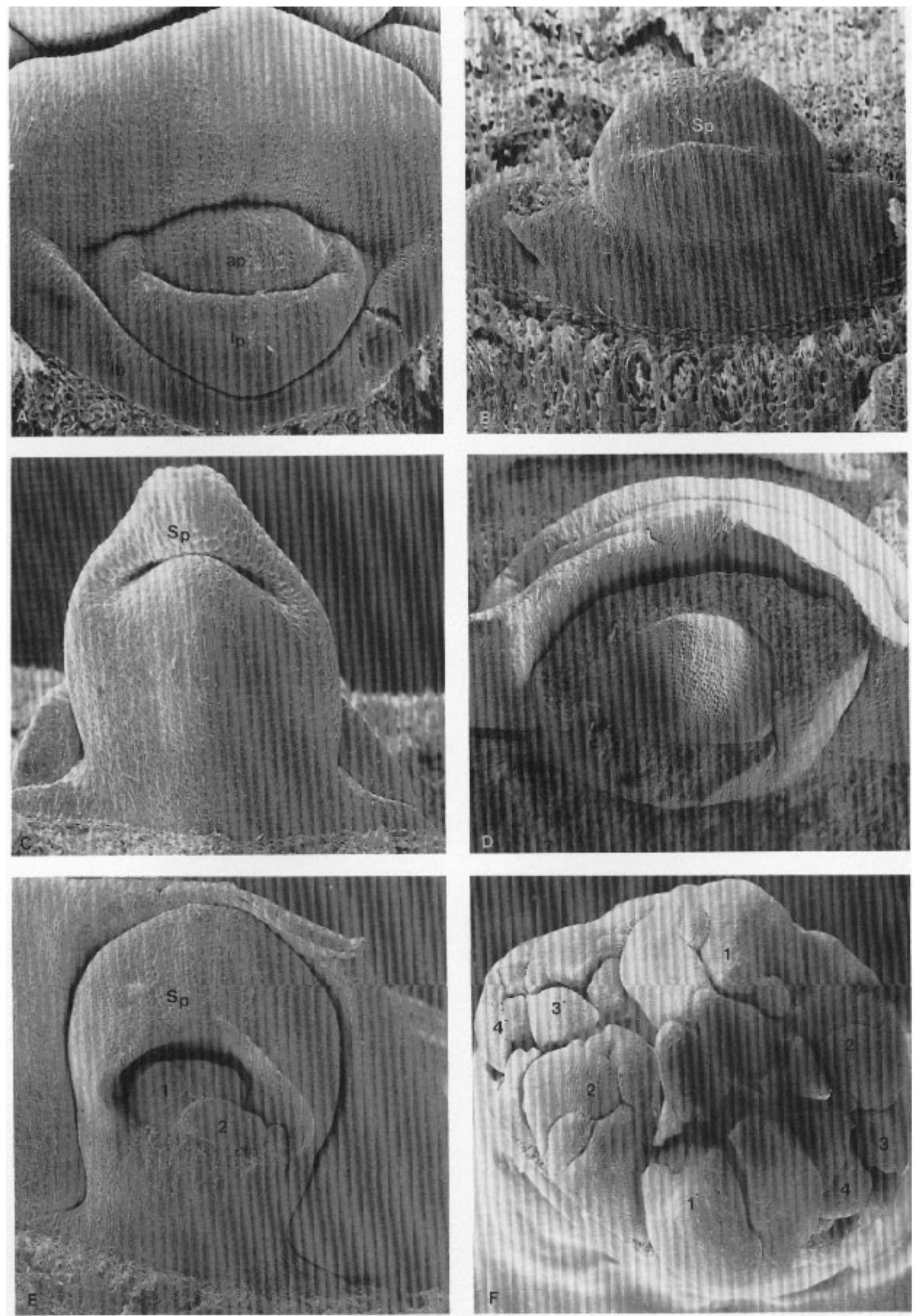

Fig. 2. Development of the apical meristem of Nerine bowdenii from the vegetative stage (I) to the end of floret initiation. (A) Vegetative apex (ap) with leaf primordia (lp) initiating; leaf base (lb) encircles apical meristem, $\times 36$. (B) Early spathe (Sp) development, $\times 42$. (C) Later spathe development, $\times 42$. (D) Spathe removed, apical dome exposed; dome slightly uneven, $\times 42$. (E) Inflorescence with one spathe valve (Sp) removed; two floret primordia visible; prophyll behind inflorescence, $\times 21$. (F) Inflorescence with both spathe valves removed; eight florets present, four per bostryx, $\times 13$. 

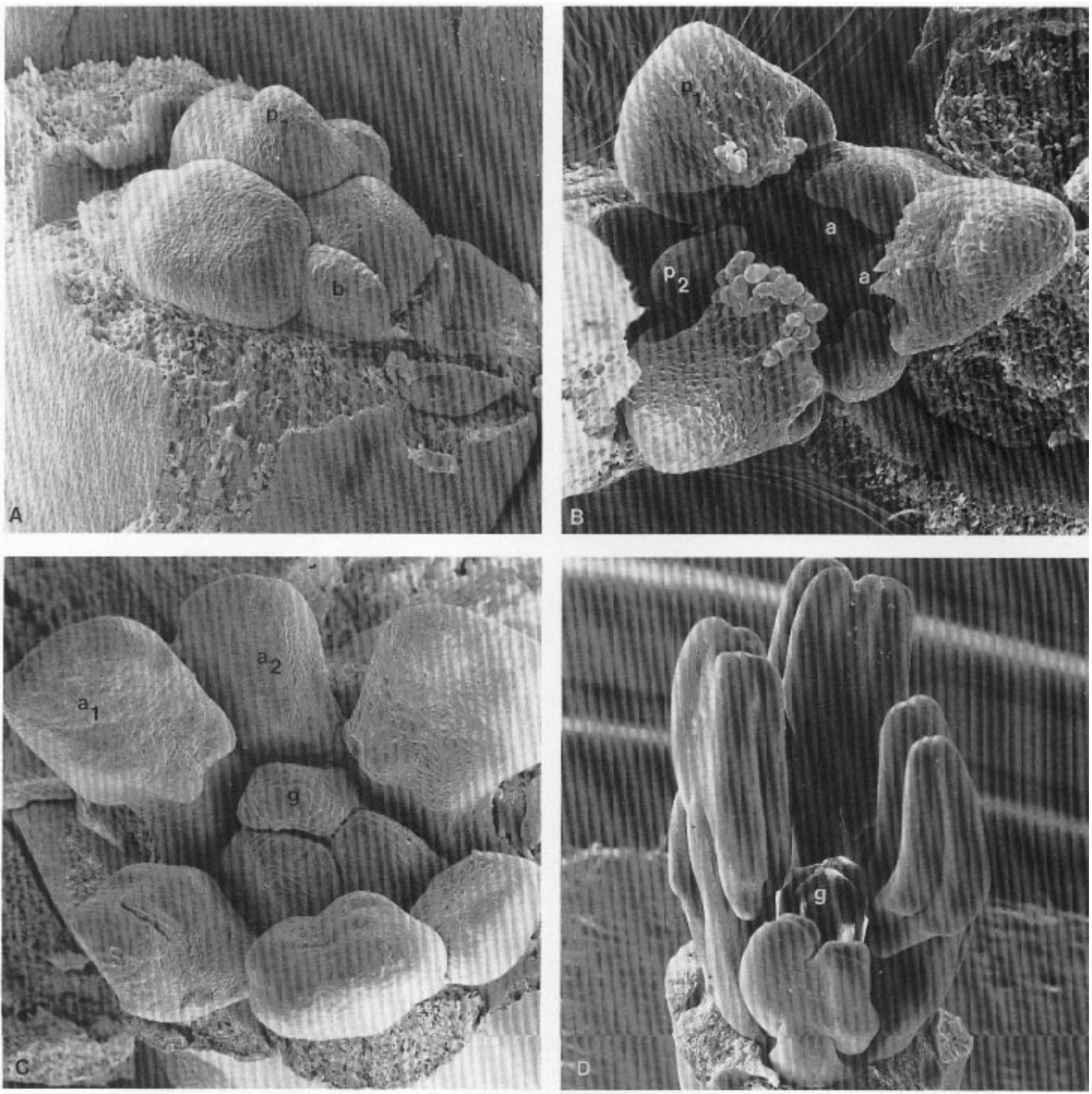

Fig. 3. Development of a single floret of Nerine bowdenii from stage P1 to stage Late G. (A) Oldest floret (first floret in first bostryx) at stage P1 initiating first whorl of perianth (p1); second floret primordium (first floret of second bostryx) slightly uneven as stage P1 is about to commence; third floret primordium with bracteole (b), $\times 42$. (B) Floret at stage $A_{2}$ with two perianth whorls $\left(p_{1}\right.$ and $\left.p_{2}\right)$ and two whorls of androecium (a), $\times 42$. (C) Floret at stage Mid G with perianth removed; two whorls of androecia $\left(a_{1}\right.$ and $\left.a_{2}\right)$ and three unfused carpels $(g), \times 42$. (D) Floret at stage Late $\mathrm{G}$ with perianth removed; gynoecium elongated and carpels fused, $\times 14$.

when inflorescence $\mathrm{N}+2$ was initiated. Younger florets (numbers 5 to 7 ) in inflorescence $\mathrm{N}+1$ also developed to stage $\mathrm{A} 2$ or Early $\mathrm{G}$ before winter (data not presented). Therefore, low temperatures are not a prerequisite for floret initiation and differentiation at least until stage Early G. The time required from floret initiation until stage Early $\mathrm{G}$ was shorter for the younger florets when compared to the older florets in an inflorescence. The spathe of inflorescence $\mathrm{N}+1$ had increased slightly in length from planting until the oldest floret reached stage Mid G and inflorescence $\mathrm{N}+2$ was initiated. No further elongation took place during fall and winter (Fig. 4). The floret initiation phase extended over a 1-year period. Develop- ment of the florets are arrested at stage Mid G, in sequence from the oldest to the youngest, to synchronize their development, as anthesis of individual florets in an inflorescence occurs over a few days only.

At planting, the oldest floret in inflorescence $\mathrm{N}$ was at stage $\mathrm{Mid}$ G. After planting, no additional florets were initiated in inflorescence N. Florets developed slowly until the oldest floret had reached stage Late G. Rapid elongation of the scape occurred and the spathe dehisced just before full flower in Fall 1991. This rapid elongation occurred just before the initiation of inflorescence $\mathrm{N}+2$ (Fig. 4). Richards (1990) found that meiosis in the anthers occurred 


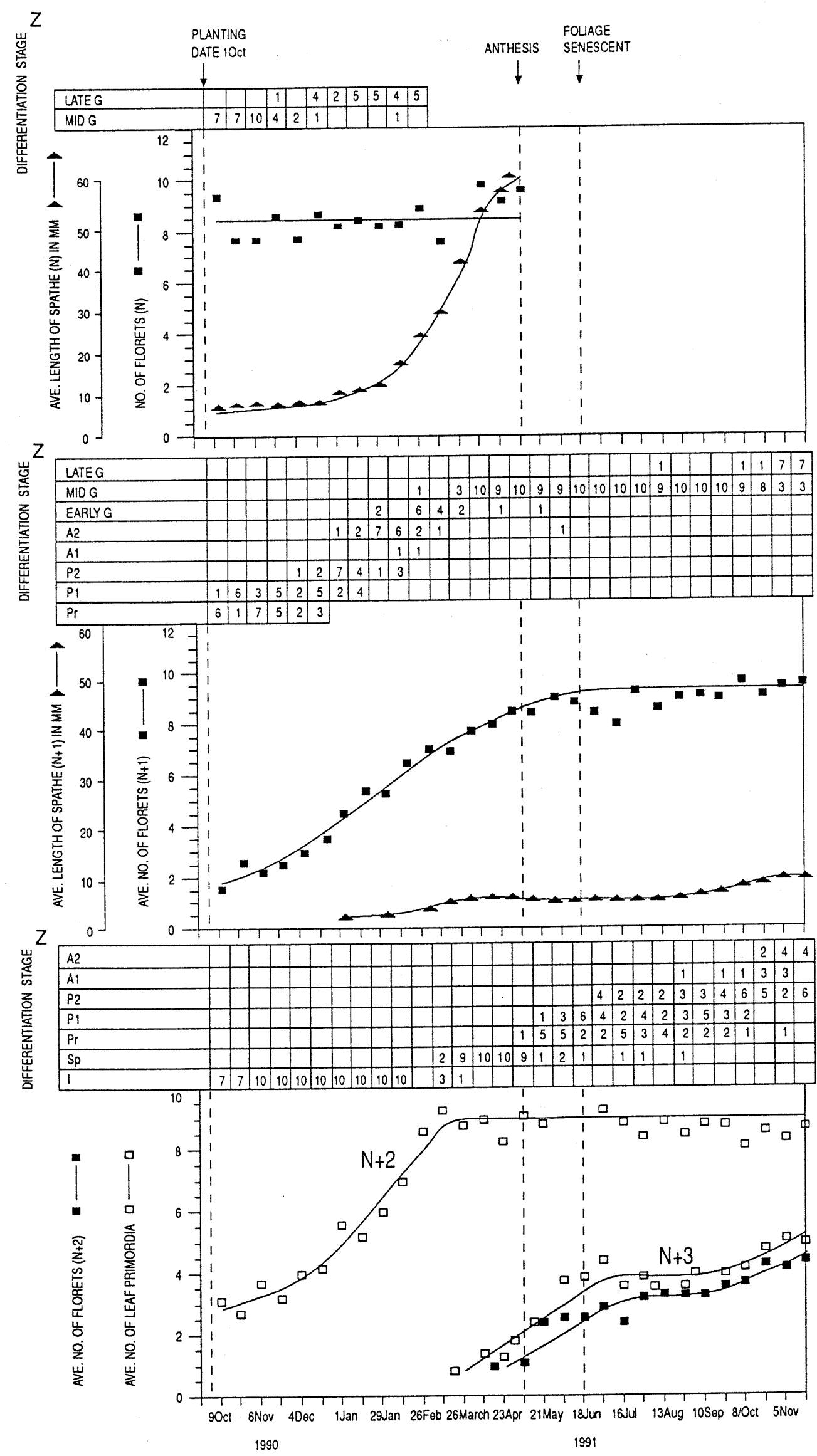

Fig. 4. Seasonal development of the growth cycles of Nerine bowdenii bulbs for 14 months following planting on 1 Oct. 1990. Number of bulbs with an inflorescence or a floret at the specific differentiation stage. 
during this last stage of development. Anthesis of inflorescence $\mathrm{N}+1$ in 1992 was nearly 1 month earlier than that of inflorescence $\mathrm{N}$ in 1991 (data not presented). This was due to the earlier development of bulbs left in situ during the winter.

Synchronization of development seems to exist among the inflorescences of different growth units. As soon as florets in inflorescence $\mathrm{N}$ reach stage Late $\mathrm{G}$, the spathe starts to elongate. Subsequently, florets in inflorescence $\mathrm{N}+1$ reach the Mid G stage and inflorescence $\mathrm{N}+2$ is initiated. Inflorescence development goes through three phases, 1 ) a floret initiation phase, of $\approx 1$ year, when nine to ten florets are initiated, 2) a differentiation phase, which also lasts $\approx 1$ year, when individual florets develop up to stage Late $\mathrm{G}$, and 3) an inflorescence enlargement phase, which lasts $\approx 4$ months and culminates in anthesis.

The average number of leaves in each growth unit of Amaryllidaceae bulbs is species dependent. We found between eight and nine fully sheathing leaves in Nerine bowdenii, while there are 11 in A. belladonna (Hartsema and Leupen, 1942), three in Galanthus nivalis L. (Luyten and Van Waveren, 1952), 15 in Haemanthus katherinae (now Scadoxus multiflorus ssp. katherinae) (Peters, 1971), four in Hippeastrum hybridum (Blaauw, 1931), seven to eight in Leucojum aestivum L. (Luyten and Van Waveren, 1938), five in Lycoris radiata, and ten in L. squamigera (Mori and Sakanishi, 1977).

In A. belladonna (Hartsema and Leupen, 1942) and Hippeastrum hybridum (Blaauw, 1931), reproductive development also starts immediately after the initiation of the last leaf primordium. However, in Galanthus nivalis (Luyten and Van Waveren, 1952), Scadoxus multiflorus ssp. katherinae (Peters, 1971), and Lycoris radiata (Mori and Sakanishi, 1977), several months passed between the initiation of the last leaf primordium and the beginning of inflorescence initiation. In all these Amaryllidaceae, the new vegetative cycle starts immediately after the initiation of the flower or inflorescence (Blaauw, 1931; Hartsema and Leupen, 1942; Luyten and Van Waveren, 1938, 1952; Mori and Sakanishi, 1977; Peters, 1971).

In other Amaryllidaceae the period from initiation to anthesis of inflorescences is shorter than the 26 months required for Nerine bowdenii. This period lasts 12 to 13 months in Amaryllis belladonna (Hartsema and Leupen, 1942), 18 to 24 months in Hippeastrum hybridum (Blaauw, 1931), 11 months in Galanthus nivalis (Luyten and Van Waveren, 1952), 8 months in Leucojum aestivum (Luyten and Van Waveren, 1938), and 18 months in Nerine sarniensis (Rees, 1985). Galanthus nivalis requires only 3 months to differentiate its flower, but nearly 8 months are needed before development commences and anthesis is reached (Luyten and Van Waveren, 1952). Also, in Scadoxus multiflorus ssp. katherinae, 7 months pass from the time the youngest floret reach stage G until anthesis (Peters, 1971). In Leucojum aestivum this period is 6 months long (Luyten and Van Waveren, 1938); whereas, in Lycoris spp. there is no apparent period of arrested development (Mori and Sakanishi, 1977).

\section{Literature Cited}

Beyer, J.J. 1942. De terminologie van de bloemaanleg der bolgewassen. Meded. Landbouwhoogesch. Wageningen 46(5):1-17.

Berghoef, J. and G. Van Brenk. 1983. Effect of temperature on flowering of Nerine bowdenii W. Watts. Acta Hort. 134:41-48.

Blaauw, A.H. 1931. Orgaanvorming en periodiciteit van Hippeastrum hybridum. Verh. K. Akad. Wet. (Sect. 2) 29(1):1-90.

Dalgren, R.M.T., M.T. Clifford, and P.F. Yeo. 1985. The families of the monocotyledons. Springer-Verlag, Berlin.

Department of Agriculture and Water Supplies. 1989. Climatic statistics for the winter rainfall region. Sect. Agromet., Elsenburg, Rep. S. Africa.

Du Plessis, N. and G. Duncan. 1989. Bulbous plants of Southern Africa-A guide to their cultivation and propagation. Tafelberg Publishers, Cape Town.

Hartsema, A.M. and F.F. Leupen. 1942. Orgaanvorming en periodiciteit van Amaryllis belladonna. Meded. Landbouwhoogesch. Wageningen 46(4):1-30.

Luyten, I. and J.M. Van Waveren. 1938. De orgaanvorming van Leucojum aestivum L. Meded. Landbouwhoogesch. Wageningen 42(1):1-24.

Luyten, I. and J.M. Van Waveren. 1952. De orgaanvorming van Galanthus nivalis L. Meded. Landbouwhoogesch. Wageningen 52(4):105-124.

Mori, G. and Y. Sakanishi. 1977. Studies on the growth and flowering of bulbous plants of Amaryllidaceae 1. Growth and flowering of Lycoris plants grown in the field. J. Jpn. Soc. Hort. Sci. 45(4):389-396.

Nell, T.A. and H.P. Rasmussen. 1979. Floral development and blindness in roses: A SEM study. J. Amer. Soc. Hort. Sci. 104:18-20.

Peters, J. 1971. Über die periodische Entwickelung von Haemanthus katharinae cv. 'König Albert'. Gartenbauwissenschaft 36:461-470.

Rees, A.R. 1985. Nerine, p. 297-299. In: A.H. Halevy (ed.). CRC Handbook of flowering. vol. 1. CRC Press, Boca Raton, Fla.

Richards, M. 1990. Tissue culture studies on Nerine bowdenii W. Watts. MS thesis. Univ. of Stellenbosch, Stellenbosch, Rep. S. Africa.

Sytsema, W. 1971. Effect of storage and date of planting on flowering and bulb growth of Nerine bowdenii. Acta Hort. 23:99-105.

Van Brenk, G. and M. Benschop. 1993. Nerine, p. 559-588. In: A. de Hertogh and M. le Nard (ed.). The physiology of flower bulbs. Elsevier, Amsterdam.

Van Dijk, P. 1988. In: Bloementeeltinformatie no. 21. Proefstation voor de bloemisterij te Aalsmeer, The Netherlands. p. 6-9. 